\title{
Antena Susun Berpolarisasi Sirkular dengan Menggunakan Distribusi Daya Dolph Tschebycheff \\ (Circularly Polarized Array Antenna Using Dolph Tschebycheff Power Distribution)
}

\author{
Citra Zaskia Pratiwi ${ }^{1}$, Achmad Munir ${ }^{2}$
}

\begin{abstract}
This paper discusses the design and realization of circularly polarized array antenna using Dolph Tschebycheff power distribution. The advantages of implementing circular polarization yield the array antenna suitable for outdoor communication system and can minimize the Faraday effect. The Dolph Tschebycheff power distribution is used to suppress the side lobe of array antenna. The proposed array antenna, which is intended to operate at the frequency of $5.3 \mathrm{GHz}$, consists of five square patch elements with seven diagonal slots upon each element to enhance the bandwidth and to produce the circular polarization. The array antenna is designed and realized using two layers of FR-4 epoxy dielectric substrate with the dimension of $119 \mathrm{~mm} \times 44.1 \mathrm{~mm}$ and the thickness of $0.8 \mathrm{~mm}$ for each dielectric substrate. Each patch element is fed using a proximity coupling technique excited through a $50 \Omega$ SMA connector. The measurement results show the bandwidth of $720 \mathrm{MHz}$, the side lobe level of $12.39 \mathrm{~dB}$, the gain of more than $6 \mathrm{dBi}$ around the frequency of $5.3 \mathrm{GHz}$, and the $3 \mathrm{~dB}$ axial ratio bandwidth of 200 MHz. It seems that the realized array antenna could produce wide bandwidth, low side lobe level, and circular polarization, so that it is suitable for WLAN application.
\end{abstract}

Intisari-Makalah ini membahas perancangan dan realisasi antena susun berpolarisasi sirkular menggunakan distribusi daya Dolph Tschebycheff. Kelebihan dari penerapan polarisasi sirkular menjadikan antena susun cocok untuk sistem komunikasi outdoor dan dapat meminimalisasi efek Faraday. Distribusi daya Dolph Tschebycheff digunakan untuk menekan side lobe dari antena susun. Antena susun yang diperuntukkan bekerja pada frekuensi $5,3 \mathrm{GHz}$ ini terdiri atas lima elemen patch berbentuk persegi dengan tujuh slot diagonal pada setiap elemennya untuk meningkatkan bandwidth dan menghasilkan polarisasi sirkular. Antena susun dirancang dan direalisasikan menggunakan dua lapis substrat dielektrik epoxy FR-4 dengan dimensi sebesar $119 \mathrm{~mm} \times 44,1 \mathrm{~mm}$ dan ketebalan sebesar 0,8 mm untuk setiap substrat dielektrik. Setiap elemen patch dicatu menggunakan teknik proximity coupling yang dieksitasi melalui sebuah konektor SMA $50 \Omega$. Hasil pengukuran menunjukkan bandwidth sebesar $720 \mathrm{MHz}$, side lobe level sebesar 12,39 dB, gain lebih dari $6 \mathrm{dBi}$ di sekitar frekuensi 5,3 GHz, dan bandwidth axial ratio $3 \mathrm{~dB}$ sebesar $200 \mathrm{MHz}$. Terlihat bahwa antena susun yang direalisasikan dapat menghasilkan bandwidth yang lebar,

\footnotetext{
1 Program Studi Mekanisasi Perikanan, Politeknik Kelautan dan Perikanan Sidoarjo, Jalan Raya Buncitan Kotak Pos 1, Sidoarjo 61253 INDONESIA (telp: 031-8911380; email: citra.zaskia@apsidoarjo.ac.id)

${ }^{2}$ Sekolah Teknik Elektro dan Informatika, Institut Teknologi Bandung, Jalan Ganesha 10, Bandung 40132 INDONESIA (telp: 022-2502260; e-mail: munir@ieee.org)
}

side lobe level yang rendah, dan polarisasi sirkular, sehingga cocok untuk aplikasi WLAN.

Kata Kunci-Antena Susun, Polarisasi Sirkular, Slot, Proximity Coupling, Patch Persegi, Distribusi Daya Dolph Tschebycheff.

\section{PENDAhUluan}

Perkembangan teknologi selama beberapa dekade terakhir mengalami pertumbuhan pesat terutama dalam komunikasi wireless dan sistem radar [1]-[2]. Sistem komunikasi wireless seperti Wireless Local Area Network (WLAN) dan Long Term Evolution (LTE) cenderung memanfaatkan kecepatan tinggi dan data yang besar sehingga membutuhkan perangkat (antena) dengan kinerja tinggi [2]. Salah satu jenis antena yang biasa digunakan dalam sistem komunikasi wireless dan sistem radar adalah antena mikrostrip, karena memiliki kelebihan antara lain ukuran antena kecil, ringan, biaya produksi murah, dan mudah difabrikasi [3]. Antena mikrostrip juga dapat menghasilkan polarisasi linier dan sirkular. Kelebihan dari polarisasi sirkular jika dibandingkan dengan polarisasi linier adalah cocok digunakan untuk sistem komunikasi outdoor dan dapat meminimalisasi efek Faraday yang muncul pada komunikasi wireless [4]-[5].

Namun, antena mikrostrip juga memiliki kekurangan, yaitu menghasilkan bandwidth yang sempit [6]-[7]. Ada beberapa metode yang dapat digunakan untuk meningkatkan bandwidth, salah satunya adalah dengan menggunakan slot [8]-[10]. Pada penelitian sebelumnya, dihasilkan bandwidth sebesar $60 \mathrm{MHz}$ sehingga diperlukan peningkatan bandwidth yang lebih signifikan [9]. Antena mikrostrip dengan menggunakan slot dapat menghasilkan bandwidth yang besar tetapi menghasilkan gain yang rendah jika hanya terdiri atas elemen tunggal. Banyak aplikasi juga membutuhkan karakteristik radiasi yang tidak dapat dihasilkan oleh antena mikrostrip dengan elemen tunggal. Oleh karena itu, antena mikrostrip disusun lebih dari satu elemen untuk meningkatkan gain dan menghasilkan karakteristik radiasi tertentu [11]-[12]. Karakteristik radiasi yang baik merupakan persyaratan dalam sistem komunikasi wireless. Selain memiliki kelebihan, antena susun juga memiliki kekurangan, yaitu menghasilkan side lobe. Untuk menekan side lobe digunakan distribusi daya Dolph Tschebycheff dan Binomial [13]-[15]. Pada distribusi daya Dolph Tschebycheff digunakan polinomial Tschebycheff untuk mendapatkan susunan optimum untuk side lobe level tertentu. Penekanan side lobe level telah dilakukan, tetapi besarnya penekanan side lobe level belum optimal [13]. 


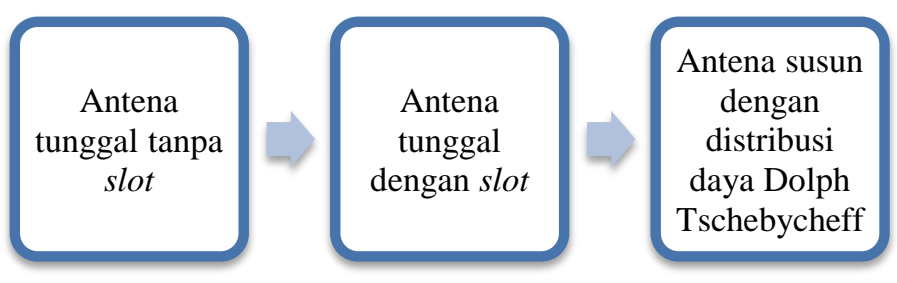

Gbr. 1 Tahapan perancangan antena susun.

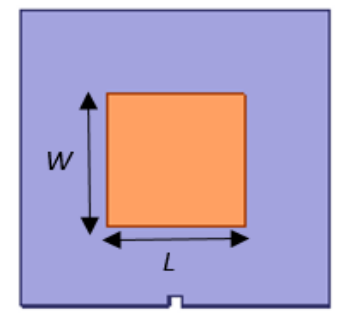

(a)

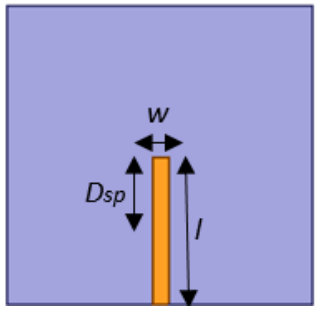

(b)
Gbr. 2 Desain antena tunggal tanpa slot, (a) substrat pertama, (b) substrat kedua.

Makalah ini menjelaskan tentang perancangan antena susun, yaitu pada Bagian II, realisasi dan pengukuran antena susun pada Bagian III, dan kesimpulan pada Bagian IV. Antena tersusun dari lima elemen patch berbentuk persegi dengan menggunakan distribusi daya Dolph Tschebycheff. Slot diletakkan secara diagonal di bagian atas patch persegi untuk meningkatkan bandwidth dan menghasilkan polarisasi sirkular. Jumlah slot yang digunakan adalah tujuh slot berbentuk persegi panjang. Teknik pencatuan yang digunakan adalah proximity coupling yang berada di antara dua substrat dielektrik epoxy FR-4 dengan ketebalan 0,8 mm. Antena susun ini bekerja pada frekuensi 5,3 GHz dan dapat digunakan untuk aplikasi WLAN. Selain itu, antena susun dirancang untuk menghasilkan bandwidth yang lebar dengan side lobe level yang rendah.

\section{Perancangan Antena Susun}

Antena susun mikrostrip dirancang dengan menggunakan dua lapis substrat dielektrik epoxy FR-4 yang memiliki permitivitas relatif $\left(\varepsilon_{r}\right)$ sebesar 4,3 dengan ketebalan masingmasing $0,8 \mathrm{~mm}$. Pada bagian atas substrat pertama terdiri atas lima elemen patch berbentuk persegi, sedangkan pada bagian atas substrat kedua digunakan untuk teknik pencatuan proximity coupling yang dihubungkan dengan konektor SMA $50 \Omega$. Antena susun bekerja pada frekuensi 5,3 GHz, yang digunakan untuk aplikasi WLAN.

Tahapan perancangan antena terdiri atas antena tunggal tanpa slot, antena tunggal dengan slot, dan antena susun dengan distribusi daya Dolph Tschebycheff, seperti yang ditunjukkan pada Gbr. 1.

\section{A. Antena Tunggal tanpa Slot}

Proses awal perancangan antena adalah menentukan ukuran patch antena dengan menggunakan (1).

$$
l_{p}=\frac{c}{2 f_{o} \sqrt{\varepsilon} r}
$$

TABEL I

DIMENSI ANTENA TUNGGAL TANPA SLOT

\begin{tabular}{|l|l|}
\hline \multicolumn{1}{|c|}{ Parameter Antena } & \multicolumn{1}{c|}{ Nilai } \\
\hline Panjang $(L) \times$ Lebar $(W)$ patch & $13 \mathrm{~mm} \times 13 \mathrm{~mm}$ \\
\hline Panjang $(L) \times$ Lebar $(W)$ substrat & $29,1 \mathrm{~mm} \times 29,1 \mathrm{~mm}$ \\
\hline Ketebalan patch $(t)$ & $0,035 \mathrm{~mm}$ \\
\hline Ketebalan substrat $(h)$ & $0,8 \mathrm{~mm}$ \\
\hline Lebar saluran pencatu $(w)$ & $1,5 \mathrm{~mm}$ \\
\hline Jarak penyisipan saluran $(D s p)$ & $6,6 \mathrm{~mm}$ \\
\hline Panjang saluran pencatu $(l)$ & $14,4 \mathrm{~mm}$ \\
\hline
\end{tabular}

dengan $l_{p}, c, f_{o}$, dan $\varepsilon_{r}$ menyatakan panjang patch, kecepatan cahaya dalam ruang hampa, frekuensi operasi, dan permitivitas relatif. Antena tunggal tanpa slot ditunjukkan pada Gbr. 2. Antena bekerja pada frekuensi 5,3 GHz. Lebar saluran transmisi untuk impedans $50 \Omega$ sebesar $1,5 \mathrm{~mm}$ dengan menggunakan (2)-(5). Dimensi antena tunggal tanpa slot ditunjukkan pada Tabel I.

$$
\begin{aligned}
& \text { untuk } \frac{w}{h} \leq 2 \\
& \qquad \frac{w}{h}=\frac{8 e^{A}}{e^{2 A}-2} \\
& A=\frac{Z_{0}}{60} \sqrt{\frac{\varepsilon_{r}+1}{2}}+\frac{\varepsilon_{r}-1}{\varepsilon_{r}+1}\left(0,23+\frac{0,11}{\varepsilon_{r}}\right)
\end{aligned}
$$

$\operatorname{untuk} \frac{w}{h}>2$

$$
\begin{gathered}
\frac{w}{h}=\frac{2}{\pi}\left[\begin{array}{c}
B-1-\ln (2 B-1) \\
+\frac{\varepsilon_{r}-1}{2 \varepsilon_{r}}\left(\ln (B-1)=0,39-\frac{0,61}{\varepsilon_{r}}\right)
\end{array}\right] \\
B=\frac{377 \pi}{2 Z_{0} \sqrt{\varepsilon_{r}}}
\end{gathered}
$$

dengan $Z_{0}, w, h, \varepsilon_{r}$ menyatakan impedans karakteristik, lebar saluran pencatu, tebal substrat, dan permitivitas relatif.

\section{B. Antena Tunggal dengan Slot}

Setelah dilakukan perancangan antena tanpa slot, kemudian dilakukan penambahan slot diagonal pada bagian atas patch. Optimisasi dengan perubahan beberapa parameter digunakan untuk mendapatkan bandwidth yang paling lebar dan kinerja antena terbaik. Parameter yang diamati adalah panjang slot, lebar slot, jumlah slot, dan jarak slot.

1) Pengaruh Panjang Slot: Panjang slot merupakan parameter yang menentukan bandwidth. Simulasi dilakukan dengan menggunakan lebar awal slot sebesar 0,2 mm dengan perubahan panjang slot (Ls) dari 6,4 mm sampai 7,6 mm untuk diamati pengaruh panjang slot terhadap pelebaran bandwidth. Jumlah slot yang digunakan sebesar satu slot. Hasil simulasi pada Gbr. 3 menunjukkan bahwa semakin 


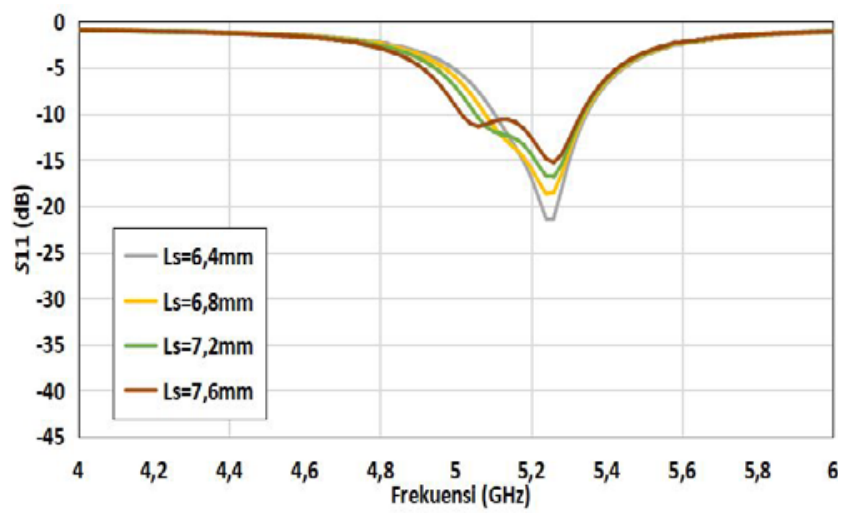

Gbr. 3 Pengaruh panjang slot terhadap nilai koefisien refleksi $\left(S_{11}\right)$.

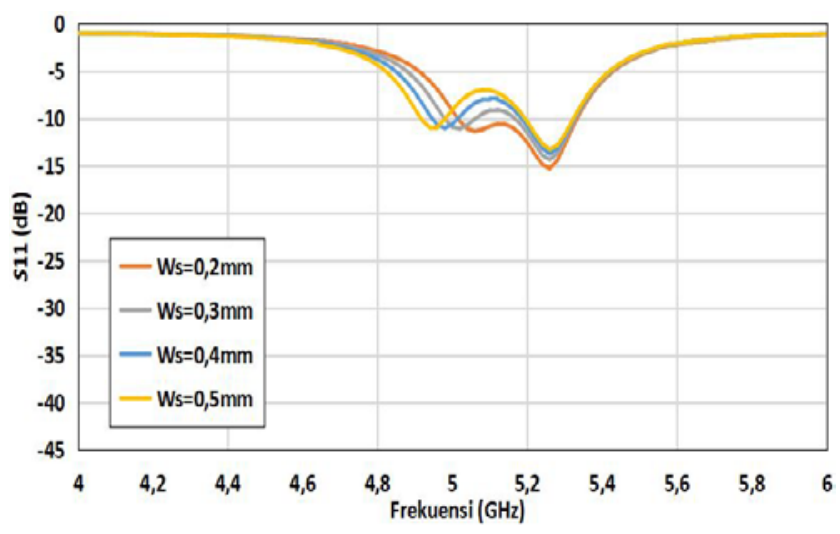

Gbr. 4 Pengaruh lebar slot terhadap nilai koefisien refleksi $\left(S_{11}\right)$.

panjang slot, semakin lebar bandwidth. Panjang slot sebesar 7,6 mm digunakan untuk optimisasi selanjutnya, karena memiliki bandwidth yang lebar dan nilai koefisien refleksi $\left(S_{11}\right)$ yang paling baik.

2) Pengaruh Lebar Slot: Optimisasi selanjutnya adalah perubahan lebar slot dengan lebar slot (Ws) awal yaitu 0,2 mm dan panjang slot yang digunakan adalah 7,6 mm berdasarkan hasil optimisasi sebelumnya. Hasil simulasi pada Gbr. 4 menunjukkan bahwa lebar slot memiliki pengaruh terhadap pelebaran bandwidth karena menghasilkan dua frekuensi resonansi yang berdekatan. Nilai koefisien refleksi $\left(S_{11}\right)$ akan semakin naik seiring dengan semakin lebar slot.

Berdasarkan Gbr. 4 semua nilai koefisien refleksi $\left(S_{11}\right)$ untuk lebar slot 0,2 mm berada di bawah $-10 \mathrm{~dB}$, sehingga menghasilkan bandwidth yang lebar, sedangkan untuk lebar slot $0,3 \mathrm{~mm}$ sampai $0,5 \mathrm{~mm}$ menghasilkan nilai koefisien refleksi $\left(S_{11}\right)$ di atas $-10 \mathrm{~dB}$. Namun, lebar slot $0,2 \mathrm{~mm}$ sulit untuk difabrikasi, sehingga dipilih lebar slot sebesar 0,3 mm karena memiliki nilai koefisien refleksi $\left(S_{11}\right)$ mendekati -10 $\mathrm{dB}$ dan dengan adanya optimisasi lanjutan yang tepat, akan dihasilkan bandwidth yang lebih lebar.

3) Pengaruh Jumlah Slot: Hasil simulasi menunjukkan bahwa jumlah slot berpengaruh pada pelebaran bandwidth. Perubahan jumlah slot menyebabkan rentang frekuensi resonansi semakin lebar ke arah frekuensi yang lebih rendah. Nilai koefisien refleksi $\left(S_{11}\right)$ pada bagian tengah juga semakin naik dengan semakin lebar rentang frekuensi resonansi. Hal

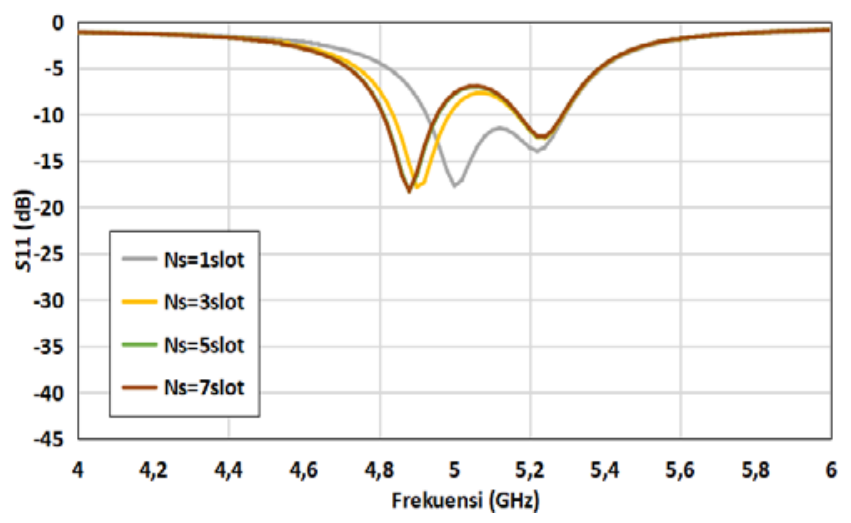

Gbr. 5 Pengaruh jumlah slot terhadap nilai koefisien refleksi $\left(S_{11}\right)$.

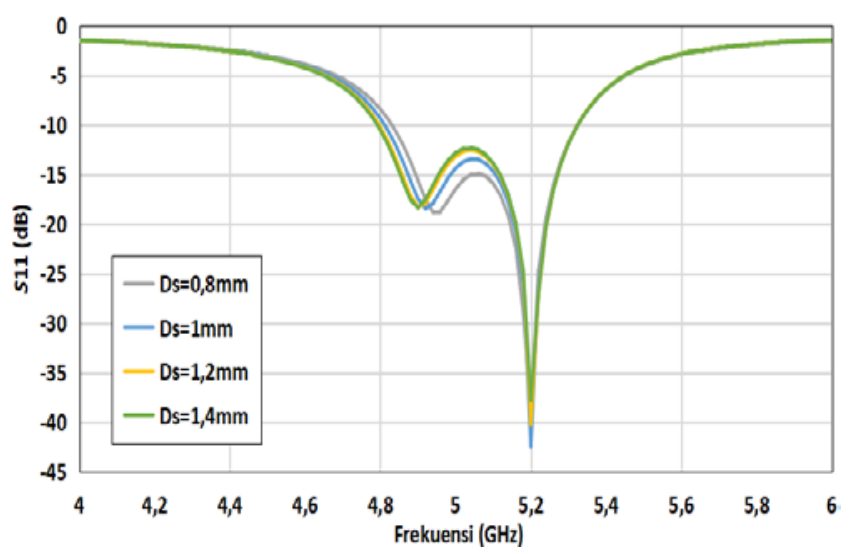

Gbr. 6 Pengaruh jarak slot terhadap nilai koefisien refleksi $\left(S_{11}\right)$.

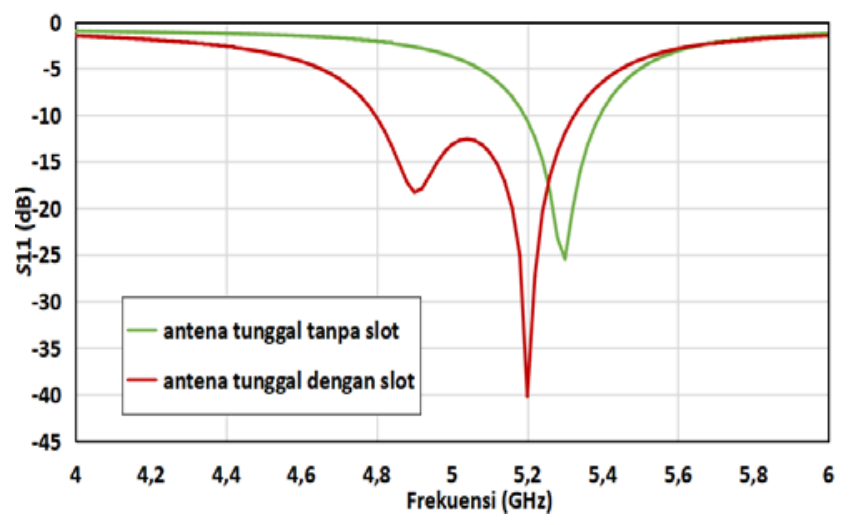

Gbr. 7 Perbandingan nilai koefisien refleksi $\left(S_{11}\right)$ antena tunggal tanpa slot dan antena tunggal dengan slot.

ini ditunjukkan oleh hasil simulasi pada Gbr. 5. Jumlah slot yang dipilih adalah sebanyak tujuh slot karena memungkinkan untuk menghasilkan bandwidth yang lebih lebar. Oleh karena itu, perlu adanya optimisasi lanjutan untuk menurunkan nilai koefisien refleksi $\left(S_{11}\right)$ pada bagian tengah, sehingga berada di bawah $-10 \mathrm{~dB}$.

4) Pengaruh Jarak Slot: Jarak slot yang digunakan sebelumnya sebesar $1 \mathrm{~mm}$, kemudian dilakukan perubahan dari 0,8 mm sampai 1,4 mm untuk diamati pengaruh jarak terhadap pelebaran bandwidth. Pada optimisasi ini digunakan lebar slot 0,3 mm dengan jumlah slot sebanyak tujuh slot. Hasil simulasi menunjukkan bahwa jarak slot 1,2 mm dan 1,4 


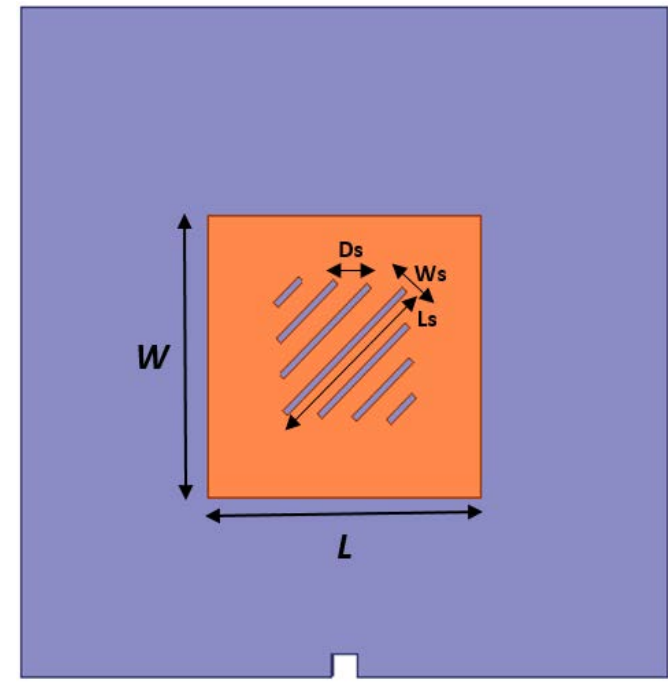

(a)

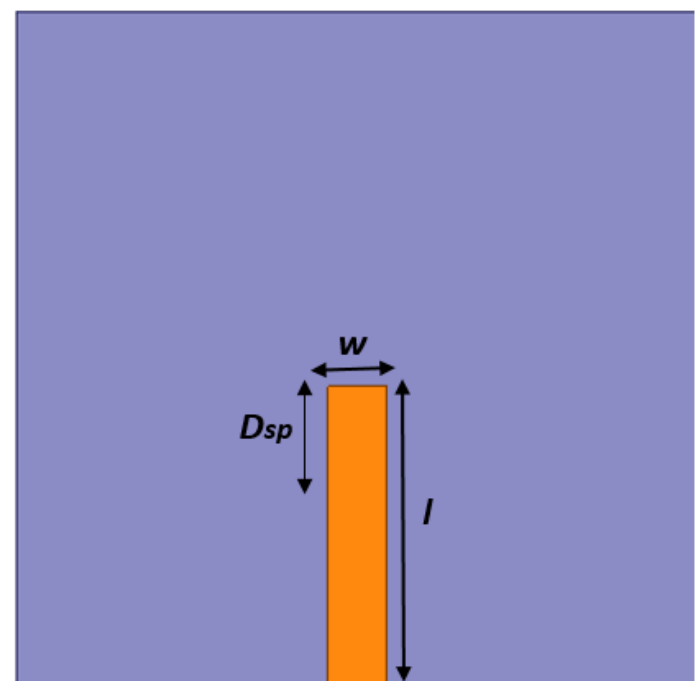

(b)

Gbr. 8 Desain antena tunggal dengan slot, (a) substrat pertama, (b) substrat kedua.

mm menghasilkan bandwidth paling lebar. Jarak slot yang dipilih adalah sebesar 1,2 mm, karena memiliki nilai koefisien refleksi $\left(S_{11}\right)$ yang lebih baik dibandingkan $1,4 \mathrm{~mm}$, berdasarkan pada Gbr. 6.

Berdasarkan nilai koefisien refleksi $\left(S_{11}\right)$, bandwidth yang dihasilkan antena tunggal tanpa slot sebesar $190 \mathrm{MHz}$, sedangkan bandwidth untuk antena tunggal dengan slot sebesar $520 \mathrm{MHz}$, seperti terlihat pada Gbr. 7. Hal ini berarti terdapat peningkatan bandwidth sebesar 173\%. Desain antena tunggal dengan slot ditunjukkan pada Gbr. 8 dan dimensi antena disajikan pada Tabel II.

\section{Antena Susun dengan Distribusi Daya Dolph Tschebycheff}

Antena susun terdiri atas lima elemen patch persegi. Di atas masing-masing patch persegi yang berada pada substrat pertama terdapat tujuh slot berbentuk persegi panjang yang diletakkan secara diagonal untuk meningkatkan bandwidth dan menghasilkan polarisasi sirkular. Selain itu, antena susun ini menggunakan distribusi daya Dolph Tschebycheff untuk menekan side lobe. Pada distribusi Dolph Tschebycheff, dicari koefisien susunan yang menentukan perbandingan daya untuk setiap elemen patch. Perbandingan main lobe terhadap side lobe $(R)$ yang dirancang untuk antena patch susun sebesar 25 dB. Prosedur perencanaan untuk mendapatkan koefisien susunan menggunakan (6)-(13).

$$
\begin{aligned}
& T_{0}(x)=1 \\
& T_{1}(x)=x \\
& T_{2}(x)=2 x^{2}-1 \\
& T_{3}(x)=4 x^{3}-3 x \\
& T_{4}(x)=8 x^{4}-8 x^{3}+1 \\
& T_{5}(x)=16 x^{5}-20 x^{3}+5 x
\end{aligned}
$$

dengan $T_{m}(x)$ menyatakan polinom Tschebycheff dengan derajat polinom $(m)=0,1,2, . ., 5$ mengacu pada (6).
TABEL II

Dimensi ANTENA TUNGGAL DENGAN SLOT

\begin{tabular}{|l|l|}
\hline \multicolumn{1}{|c|}{ Parameter Antena } & \multicolumn{1}{c|}{ Nilai } \\
\hline Panjang $(L) \times$ Lebar $(W)$ patch & $12,3 \mathrm{~mm} \times 12,3 \mathrm{~mm}$ \\
\hline Panjang $(L) \times$ Lebar $(W)$ substrat & $29,1 \mathrm{~mm} \times 29,1 \mathrm{~mm}$ \\
\hline Ketebalan patch $(t)$ & $0,035 \mathrm{~mm}$ \\
\hline Ketebalan substrat $(h)$ & $0,8 \mathrm{~mm}$ \\
\hline Lebar saluran pencatu $(w)$ & $2,5 \mathrm{~mm}$ \\
\hline Jarak penyisipan saluran $(D s p)$ & $5,1 \mathrm{~mm}$ \\
\hline Panjang saluran pencatu $(l)$ & $12,9 \mathrm{~mm}$ \\
\hline Panjang slot $(L s)$ & $7,6 \mathrm{~mm}$ \\
\hline Lebar slot $(W s)$ & $0,3 \mathrm{~mm}$ \\
\hline Jumlah slot $(N s)$ & 7 slot \\
\hline Jarak slot $(D s)$ & $1,2 \mathrm{~mm}$ \\
\hline
\end{tabular}

Susunan antena dengan elemen ganjil diperoleh dengan menggunakan (7).

$$
\begin{gathered}
E_{n}=2 \sum_{k=0}^{k=N} A_{k} \cos \left[2 k \frac{\varphi}{2}\right] \\
N=\frac{n-1}{2} \text { untuk elemen ganjil } \\
R=\frac{\text { main - lobe maximum }}{\text { sidelobe level }} \\
x_{0}=\frac{1}{2}\left[\left(R+\sqrt{R^{2}-1}\right)^{\frac{1}{m}}+\left(R-\sqrt{R^{2}-1}\right)^{\frac{1}{m}}\right] \\
\omega=\frac{x}{x_{0}} ; \omega=\cos \frac{\varphi}{2} \\
T_{n-1}(x)=E_{n}
\end{gathered}
$$


TABEL III

IMPEDANS BERDASARKAN KOEFISIEN SUSUNAN

\begin{tabular}{|c|c|}
\hline Koefisien Susunan & Impedans \\
\hline 1,00 & $100,0000 \Omega$ \\
\hline 2,04 & $49,0190 \Omega$ \\
\hline 2,56 & $39,0625 \Omega$ \\
\hline
\end{tabular}

dengan $m=n-1$ dengan $n$ adalah jumlah elemen, $E_{n}$ adalah medan listrik, $A_{k}$ adalah koefisien susunan, dan $\varphi$ adalah sudut.

Koefisien susunan yang didapatkan dengan menggunakan (6)-(13) adalah $1: 2,04: 2,56: 2,04: 1$, dengan impedans terbesar adalah $100 \Omega$, seperti pada Tabel III. Berdasarkan Tabel III, perbandingan impedans saluran pencatu untuk masing-masing elemen patch adalah $100 \Omega$ : 49,019 $\Omega$ : $39,0625 \Omega: 49,019 \Omega: 100 \Omega$. Antena susun dicatu dengan tegangan yang sama, sehingga impedans paling kecil yang berada di tengah akan memiliki daya yang besar. Impedans ditentukan oleh lebar saluran pencatu berdasarkan (14)-(17). Lebar saluran pencatu untuk impedans $100 \Omega$, 49,019 $\Omega$, dan $39,0625 \Omega$ secara berturut-turut adalah $0,36 \mathrm{~mm}, 1,62 \mathrm{~mm}$, dan 2,31 mm. Impedans paling kecil memiliki lebar saluran pencatu paling besar karena impedans berbanding terbalik dengan lebar saluran pencatu dengan menggunakan (2)-(5). untuk $\frac{w}{h} \leq 1$

$$
\begin{gathered}
Z_{0}=\frac{60}{\sqrt{\varepsilon_{\text {reff }}}} \ln \left(\frac{8 h}{w}+\frac{w}{4 h}\right) \\
\varepsilon_{\text {reff }}=\frac{\varepsilon_{r}+1}{2}+\frac{\varepsilon_{r}-1}{2}\left[1+12 \frac{h}{w}\right]^{-1 / 2}+0,04\left(1-\frac{w}{h}\right)^{2}
\end{gathered}
$$

untuk $\frac{w}{h}>1$

$$
\begin{gathered}
\frac{120 \pi}{\sqrt{\varepsilon_{\text {reff }}[w / h+1,393+0,667 \ln (w / h+1,444)]}} \\
\varepsilon_{\text {reff }}=\frac{\varepsilon_{r}+1}{2}+\frac{\varepsilon_{r}-1}{2}\left[1+12 \frac{h}{w}\right]^{-1 / 2}
\end{gathered}
$$

dengan $w, h, Z_{0}$, $\varepsilon_{\text {reff }}$ berturut-turut adalah lebar saluran pencatu, tebal substrat, impedans karakteristik, dan permitivitas relatif efektif.

Substrat pertama dan kedua memiliki ukuran yang sama, yaitu $119 \mathrm{~mm} \times 44,1 \mathrm{~mm}$. Pada antena susun ini terdapat lima saluran pencatu dengan impedans yang berbeda. Impedans $100 \Omega$ merupakan impedans untuk patch yang berada pada bagian terluar sisi kiri dan kanan. Impedans 49,019 $\Omega$ berada pada patch kedua dari luar di sisi kiri dan kanan, sedangkan impedans 39,0625 $\Omega$ merupakan impedans untuk patch bagian tengah yang memiliki daya paling besar. Nilai impedans tersebut menentukan lebar saluran pencatu pada masingmasing patch. Kelima saluran pencatu dihubungkan secara paralel dengan saluran pencatu utama menggunakan

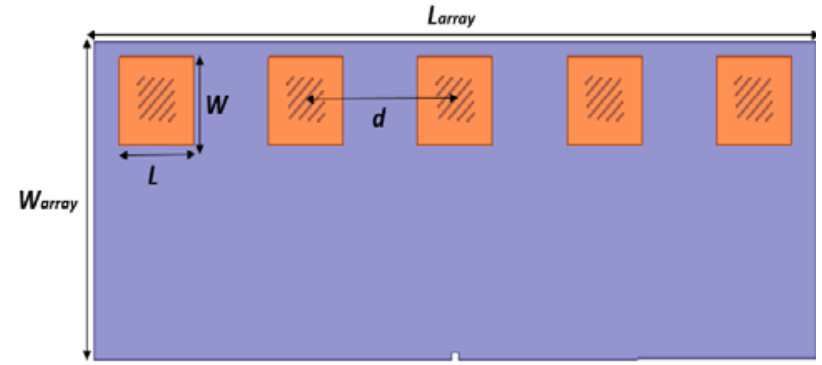

(a)

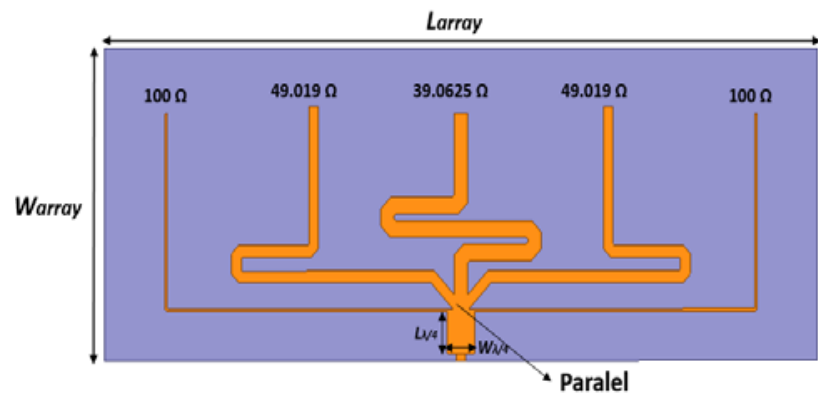

(b)

Gbr. 9 Antena susun berpolarisasi sirkular dengan distribusi daya Dolph Tschebycheff, (a) substrat pertama, (b) substrat kedua.

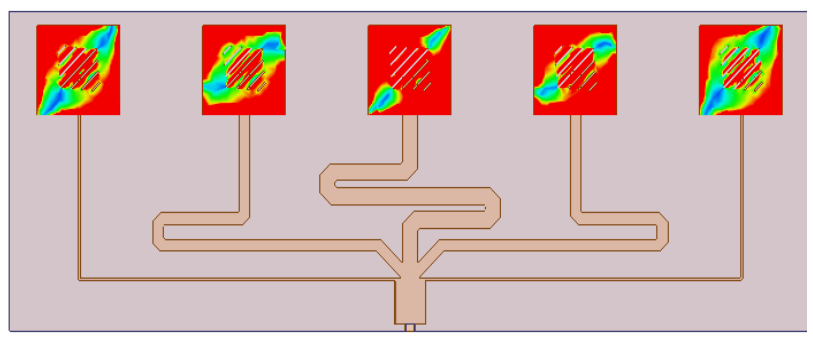

Gbr. 10 Distribusi medan listrik pada permukaan patch dari antena susun.

penyesuai impedans transformator $\lambda / 4$. Impedans paralel yang didapatkan sebesar 11,57 $\Omega$ dan impedans transformator $\lambda / 4$ sebesar 24,05 $\Omega$. Saluran pencatu utama dengan impedans 24,05 $\Omega$ memiliki lebar 4,47 mm. Panjang keseluruhan kelima saluran pencatu yang dihubungkan secara paralel adalah 76,95 $\mathrm{mm}$. Kelima saluran pencatu ini harus memiliki panjang yang sama agar sefase. Antena susun dengan distribusi daya Dolph Tschebycheff dtunjukkan pada Gbr. 9, sedangkan dimensi antena diperlihatkan pada Tabel IV. Gbr. 10 memperlihatkan distribusi medan listrik pada permukaan patch antena susun. Dari gambar tersebut tampak bahwa antena susun yang dirancang menghasilkan polarisasi sirkular karena adanya slot diagonal di bagian atas patch. Warna merah menunjukkan medan listrik paling kuat, selanjutnya kuning, hijau, dan yang paling lemah adalah biru, dengan distribusi medan listrik berada pada sisi atas patch untuk sudut $0^{\circ}$, sisi kanan patch untuk sudut $90^{\circ}$, sisi bawah patch untuk sudut $180^{\circ}$, dan sisi kiri patch untuk sudut $270^{\circ}$.

\section{REALISASI DAN PENGUKURAN ANTENA SUSUN}

Berdasarkan hasil simulasi, ukuran kedua substrat adalah $119 \mathrm{~mm} \times 44,1 \mathrm{~mm}$, sedangkan hasil fabrikasi memiliki ukuran $118 \mathrm{~mm} \times 44 \mathrm{~mm}$. Ukuran patch setelah proses 
TABEL IV

DiMENSI ANTENA SUSUN DENGAN DISTRIBUSI DOLPH TSCHEBYCHEFF

\begin{tabular}{|l|l|}
\hline \multicolumn{1}{|c|}{ Parameter Antena } & \multicolumn{1}{c|}{ Nilai } \\
\hline Ukuran patch $(L \times W)$ & $12,300 \mathrm{~mm} \times 12,300 \mathrm{~mm}$ \\
\hline Ukuran substrat $\left(\right.$ Larray $\left.\times W_{\text {array }}\right)$ & $119,000 \mathrm{~mm} \times 44,100 \mathrm{~mm}$ \\
\hline Jarak antar titik pusat patch $(d)$ & $24,600 \mathrm{~mm}$ \\
\hline Ketebalan patch $(t)$ & $0,035 \mathrm{~mm}$ \\
\hline Ketebalan substrat $(h)$ & $0,800 \mathrm{~mm}$ \\
\hline Lebar saluran pencatu $100 \Omega$ & $0,360 \mathrm{~mm}$ \\
\hline Panjang saluran pencatu $100 \Omega$ & $76,950 \mathrm{~mm}$ \\
\hline Lebar saluran pencatu $49,019 \Omega$ & $1,620 \mathrm{~mm}$ \\
\hline Panjang saluran pencatu $49,019 \Omega$ & $76,950 \mathrm{~mm}$ \\
\hline Lebar saluran pencatu $39,0625 \Omega$ & $2,310 \mathrm{~mm}$ \\
\hline Panjang saluran pencatu $39,0625 \Omega$ & $76,950 \mathrm{~mm}$ \\
\hline Lebar penyesuai impedans $\lambda / 4$ & $4,470 \mathrm{~mm}$ \\
\hline Panjang penyesuai impedans $\lambda / 4$ & $6,150 \mathrm{~mm}$ \\
\hline
\end{tabular}

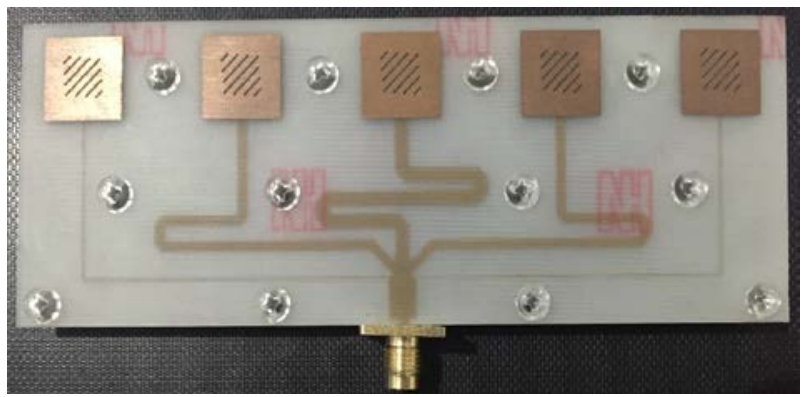

Gbr. 11 Hasil fabrikasi antena susun berpolarisasi sirkular dengan distribus daya Dolph Tschebycheff.

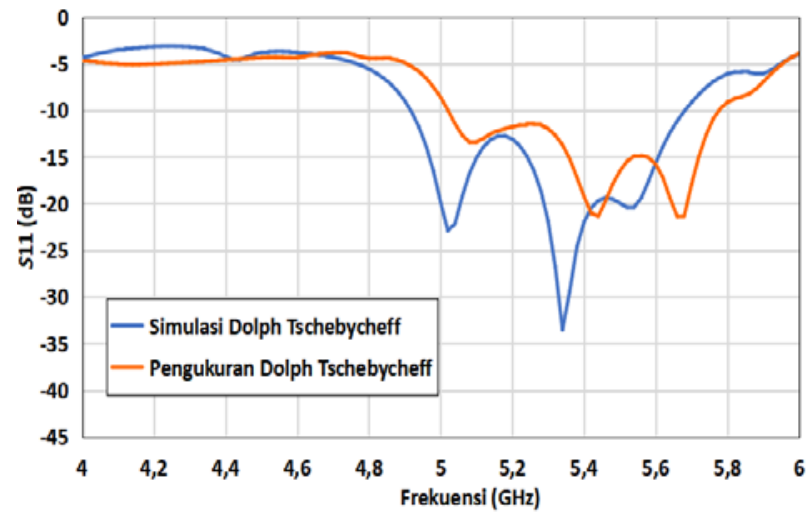

Gbr. 12 Hasil simulasi dan pengukuran koefisen refleksi $\left(\mathrm{S}_{11}\right)$ antena susun berpolarisasi sirkular dengan distribusi Dolph Tschebycheff.

fabrikasi adalah $12 \mathrm{~mm} \times 12 \mathrm{~mm}$, sedangkan ukuran sesuai perancangan adalah $12,3 \mathrm{~mm} \times 12,3 \mathrm{~mm}$. Hal ini dikarenakan adanya pembulatan pada saat proses fabrikasi. Antena susun hasil fabrikasi adalah antena dengan patch dan saluran pencatu yang menempel pada bagian substrat pertama kemudian digabungkan dengan substrat kedua dan ground plane. Saluran pencatu dihubungkan dengan konektor SMA $50 \Omega$. Hasil fabrikasi antena susun ditunjukkan pada Gbr. 11.

Proses selanjutnya adalah pengukuran antena susun yang telah direalisasikan menggunakan Vector Network Analyzer (VNA) untuk mengetahui nilai koefisien refleksi $\left(S_{11}\right)$, VSWR, pola radiasi, gain, dan axial ratio, seperti pada Gbr. 12 sampai Gbr. 16 beserta hasil simulasinya untuk dijadikan perbandingan.

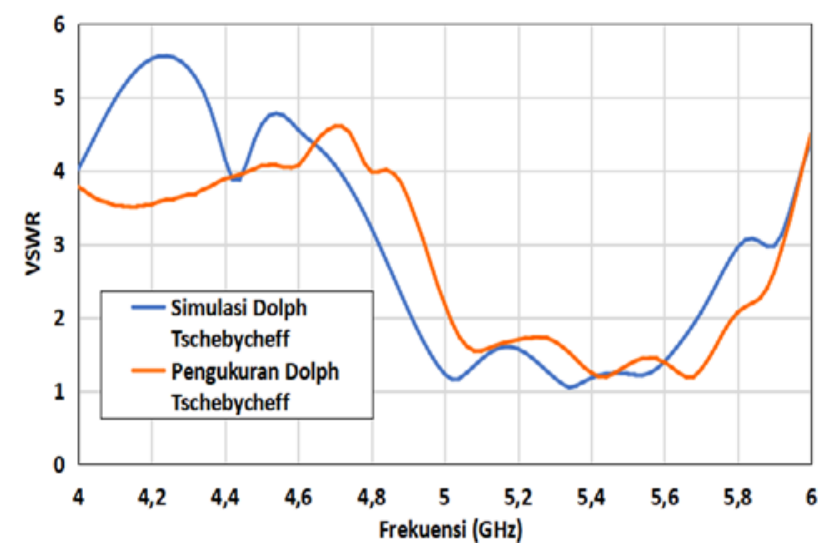

Gbr. 13 Hasil simulasi dan pengukuran VSWR antena susun berpolarisasi sirkular dengan distribusi Dolph Tschebycheff.

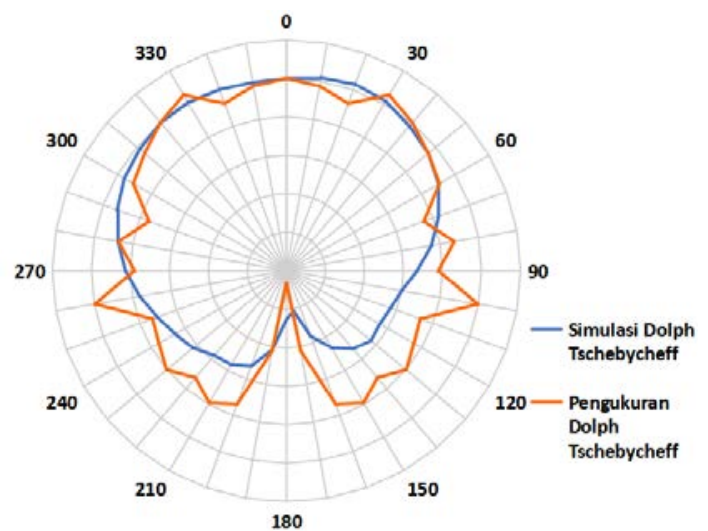

(a)

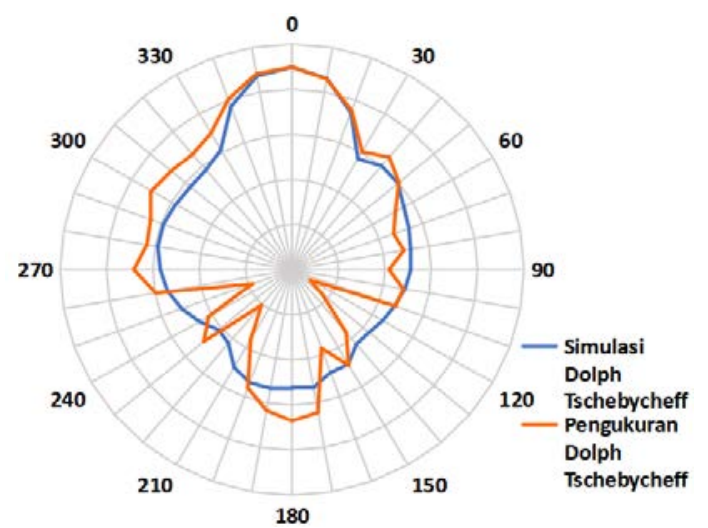

(b)

Gbr. 14 Hasil simulasi dan pengukuran pola radiasi antena susun berpolarisasi sirkular dengan distribusi Dolph Tschebycheff, (a) pola radiasi azimut, (b) pola radiasi elevasi.

Hasil simulasi menunjukkan nilai koefisien refleksi $\left(S_{11}\right)$ di bawah $-10 \mathrm{~dB}$ untuk antena dengan distribusi Dolph Tschebycheff berada pada frekuensi 4,92 GHz sampai 5,68 GHz. Hal ini berarti antena hasil simulasi memiliki bandwidth sebesar $760 \mathrm{MHz}$ dengan fractional bandwidth yaitu 14,34\%. Sementara hasil pengukuran menunjukkan nilai koefisien refleksi $\left(S_{11}\right)$ di bawah $-10 \mathrm{~dB}$ untuk frekuensi $5,04 \mathrm{GHz}$ sampai 5,76 GHz dengan bandwidth sebesar $720 \mathrm{MHz}$ dan fractional bandwidth yaitu 13,33\%. Hasil simulasi dan 


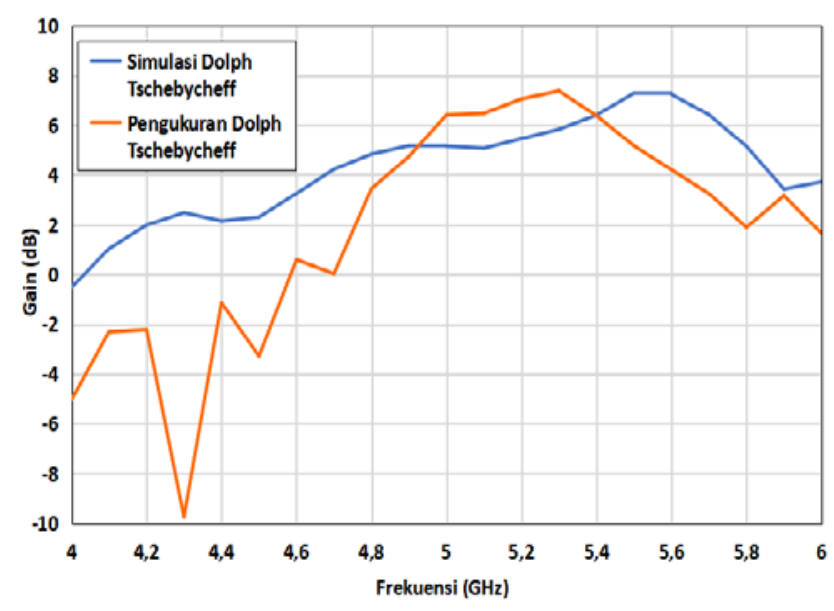

Gbr. 15 Hasil simulasi dan pengukuran gain antena susun berpolarisasi sirkular dengan distribusi Dolph Tschebycheff.

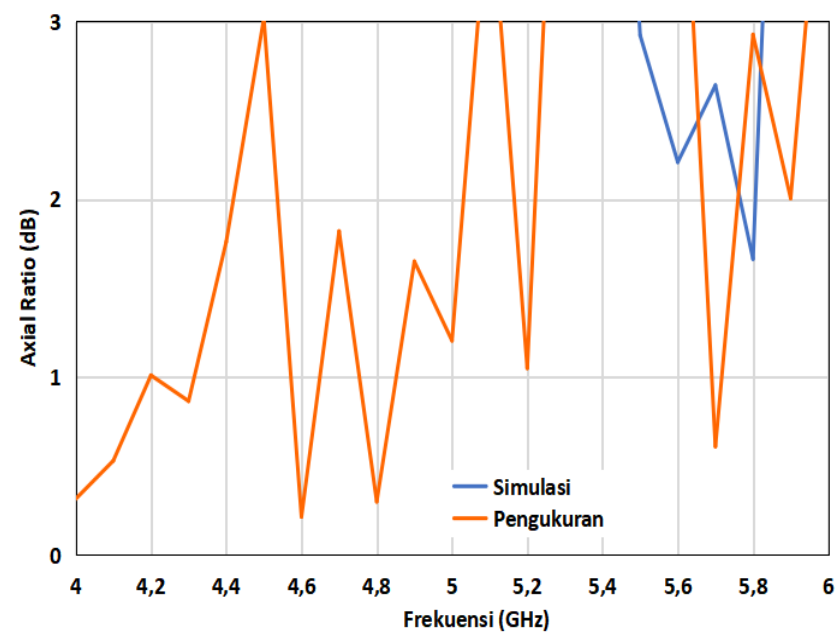

Gbr. 16 Hasil simulasi dan pengukuran axial ratio antena susun berpolarisasi sirkular dengan distribusi Dolph Tschebycheff.

pengukuran untuk koefisien refleksi $\left(S_{11}\right)$ ditunjukkan pada Gbr. 12. Berdasarkan simulasi, didapatkan nilai VSWR $<2$ pada frekuensi 4,92 $\mathrm{GHz}$ sampai 5,68 $\mathrm{GHz}$, sedangkan dari pengukuran didapatkan nilai VSWR yang baik pada frekuensi 5,04 GHz sampai 5,76 GHz, seperti pada Gbr. 13. Pola radiasi azimut menentukan besarnya side lobe level. Hasil simulasi menunjukkan side lobe level untuk distribusi Dolph Tschebycheff sebesar 14,99 dB, sedangkan pada hasil pengukuran sebesar 12,39 $\mathrm{dB}$, sehingga terdapat perbedaan sebesar 2,6 dB, seperti ditunjukkan pada Gbr. 14 .

Hasil pengukuran pada Gbr. 15 menunjukkan bahwa pada frekuensi resonansi 5,3 GHz dihasilkan gain lebih dari $6 \mathrm{dBi}$. Hal ini dikarenakan adanya gap udara antara kedua substrat dielektrik selama proses fabrikasi, sehingga menyebabkan nilai permitivitas relatif menjadi lebih kecil.

Polarisasi sirkular antena ditentukan dari nilai axial ratio $(A R)$ yang berada di bawah $3 \mathrm{~dB}$. Hasil simulasi distribusi Dolph Tschebycheff memiliki bandwidth axial ratio paling besar yaitu $300 \mathrm{MHz}$ pada rentang frekuensi 5,5 GHz sampai dengan 5,8 GHz. Bandwidth axial ratio menunjukkan rentang frekuensi yang menghasilkan nilai $A R<3 \mathrm{~dB}$, sehingga antena berpolarisasi sirkular. Hasil pengukuran polarisasi antena nilai $A R<3 \mathrm{~dB}$ berada pada frekuensi $5,7 \mathrm{GHz}$ sampai $5,9 \mathrm{GHz}$ dengan bandwidth axial ratio sebesar $200 \mathrm{MHz}$. Hasil simulasi dan pengukuran ditunjukkan pada Gbr. 16.

\section{KESIMPULAN}

Perancangan dan realisasi antena susun berpolarisiasi sirkular dengan distribusi daya Dolph Tschebyheff telah dilakukan. Antena tersusun dari lima elemen patch berbentuk persegi dengan penambahan tujuh buah slot yang diletakkan secara diagonal di bagian atas patch. Tujuannya adalah untuk meningkatkan bandwidth dan menghasilkan polarisasi sirkular. Antena susun didesain dan direalisasikan dengan menggunakan dua lapis substrat dielektrik epoxy FR-4 yang masing-masing memiliki ketebalan 0,8 mm. Selain itu, antena susun menggunakan distribusi daya Dolph Tschebycheff untuk menekan side lobe. Antena yang direalisasikan menghasilkan bandwidth sebesar $720 \mathrm{MHz}$ dengan side lobe level sebesar 12,39 $\mathrm{dB}$, sehingga memenuhi spesifikasi yang dibutuhkan untuk aplikasi WLAN.

\section{UCAPAN TERIMA KASIH}

Terima kasih disampaikan kepada Bapak Zenal Aripin, teknisi Laboratorium Telekomunikasi Radio dan Gelombang Mikro, Sekolah Teknik Elektro dan Informatika (STEI), Institut Teknologi Bandung yang membantu dalam proses pengukuran.

\section{REFERENSI}

[1] T.S. Rappaport, R.W. Heath Jr., R.C. Daniels, dan J.N. Murdock, Millimeter Wave Wireless Communications, 1st ed., Upper Saddle River, USA: Prentice Hall, 2014.

[2] A. Osseiran, J.F. Monserrat, P. Marsch, M. Dohler, dan T. Nakamura, $5 G$ Mobile and Wireless Communications Technology, 1st ed., Cambridge, UK: Cambridge University Press, 2016.

[3] R. Gusain dan S. Vijay, "Comparative Analysis of a Circularly Polarized Microstrip Antenna with a Cross-slot Using Single and Double Substrate,” International Journal of Computer Applications, Vol. 98, No. 10, hal 39-43, Jul. 2014.

[4] X. Bao dan M. J. Ammann, "Printed Circularly-polarised Antenna with Ultra-wide Axial-ratio Bandwidth,” IET Microw. Antennas Propag., Vol. 5, No. 9, hal. 1089-1096, Jun. 2011.

[5] S. Gao, Q. Luo, dan F. Zhu, Circularly Polarized Antenna, 1st ed., Hoboken, USA: Wiley-IEEE Press, 2014.

[6] V.P. Patil, "Enhancement of Bandwidth of Rectangular Patch Antenna Using Two Square Slots Techniques," International Journal of Engineering Emerging Technologies (IJESET), Vol. 3, No. 2, hal. 1-12, Okt. 2012.

[7] C.A. Balanis, Antenna Theory, Analysis and Design, 3rd ed., Hoboken, USA: John Wiley Sons Inc., 2005.

[8] C.Z. Pratiwi dan A. Munir, "A New Method of Bandwidth Widening for Square Patch Antenna Fed by Proximity Feeding Line,” Proc. 3rd International Conference on Wireless and Telematics (ICWT), 2017. hal. 98-102.

[9] N. Fadilah dan A. Munir, "Slot and Corner Truncation for Enhancing Bandwidth of Circularly Polarized Patch Antenna," Proc. 3rd International Conference on Wireless and Telematics (ICWT), 2017, hal. 31-34.

[10] F. Kurniawan, J.T.S. Sumantyo, Y.A. Nugroho, G.S. Prabowo, dan A. Munir, "A Novel Technique of Broadband Circularly Polarized Microstrip Antenna Development with Square Ring Slot for SAR Application," Proc. IEEE Conference on Antenna Measurements \& Applications (CAMA), 2018, hal. 1-4. 
[11] D. Meena dan R. S. Meena, "Gain and Directivity Enhancement of Microstrip Patch Array Antenna with Metallic Ring for WLAN/Wi-Fi Applications,” Proc. Communication, Control and Intelligent Systems (CCIS), 2015, hal. 9-11.

[12] G.M. Aji, M.A. Wibisono, dan A. Munir, "High Gain 2.4 GHz Patch Antenna Array for Rural Area Application," Proc. 22nd Asia-Pacific Conference on Communications (APCC), 2016, hal. 319-322.

[13] Y.P. Saputera, F. Oktaviani, Y. Wahyu, dan A. Munir, ”Side Lobe Supression for X-band Array Antenna Using Dolph-Chebyshev Power
Distribution,” Proc. 22nd Asia Pasific Conference on Communications, 2016, hal. 86-89.

[14] H. Mubarak, "Comparative Study of the Radiation Characteristics between Uniform, Tschebycheff, and Binomial Amplitude Distribution of Linear Patch Antenna Array for X-band Radar Warning Receivers,” Proc. International Conference on Communication, Control, Computing and Electronics Engineering, 2017, hal. 1-8.

[15] B. Sivakumar dan M.N. Ranjani, ”Design of Microstrip Antenna Array with Reduction in Sidelobes,” Proc. IEEE Conference on Antenna Measurements Applications (CAMA), 2016, hal. 1-4. 